\title{
Environmental and grazing influence on spatial variability of intertidal biofilm on subtropical rocky shores
}

\author{
Ronaldo A. Christofoletti ${ }^{1, *}$, Thiago V. V. Almeida ${ }^{2}$, Áurea M. Ciotti ${ }^{2}$ \\ ${ }^{1}$ Universidade de São Paulo, Centro de Biologia Marinha (CEBIMar/USP), Rod. Manoel Hipólito do Rego, km 131.5, \\ 11600-000, São Sebastião, SP, Brazil \\ ${ }^{2}$ Universidade Estadual Paulista 'Julio de Mesquita Filho', Campus Experimental do Litoral Paulista, \\ Unidade São Vicente, Praça Infante Dom Henrique s/n, Parque Bitarú, 11330-900, São Vicente, SP, Brazil
}

\begin{abstract}
Epilithic biofilm on rocky shores is regulated by physico-chemical and biological factors and is important as a source of food for benthic organisms. The influences of environmental and grazing pressure on spatial variability of biomass of biofilm were evaluated on shores on the north coast of São Paulo State (SE Brazil). A general trend of greater abundance of microalgae was observed lower on the shore, but neither of the environmental factors evaluated (wave exposure and shore level) showed consistent effects, and differences were found among specific shores or times (September 2007 and March 2008). The abundance of slow-moving grazers (limpets and littorinids) showed a negative correlation with chlorophyll a concentration on shores. However, experimental exclusion of these grazers failed to show consistent results at small spatial scales. Observations of divergent abundances of the isopod Ligia exotica and biomass of biofilm on isolated boulders on shores led to a short exclusion experiment, where the grazing pressure by $L$. exotica significantly decreased microalgal biomass. The result suggests that grazing activities of this fast-moving consumer probably mask the influence of slow-moving grazers at small spatial scales, while both have an additive effect at larger scales that masks environmental influences. This is the first evaluation of the impact of the fastmoving herbivore $L$. exotica on microalgal biomass on rocky shores and opens an interesting discussion about the role of these organisms in subtropical coastal environments.
\end{abstract}

KEY WORDS: Ligia exotica $\cdot$ Periphyton $\cdot$ Chlorophyll $\cdot$ Spatial patterns $\cdot$ Wave exposure $\cdot$ Grazing

\section{INTRODUCTION}

Epilithic biofilms are an important component of rocky shore ecosystems as a site for biogeochemical activities (e.g. Magalhães et al. 2003) and facilitate the settlement of macroalgae and invertebrates (Huang \& Boney 1984, Hill \& Hawkins 1991, Hung et al. 2007). These biofilms are composed of bacteria, cyanobacteria, diatoms, microalgae, protozoa, and spores of macroalgae (Anderson 1995), which make them a valuable source of organic carbon for both benthic and pelagic trophic webs (Nagarkar et al. 2004, Doi et al. 2008). Although there are studies on the role of biofilm as an important component in intertidal systems around the world (e.g. Australia: Underwood 1984a,b, MacLulich 1986, 1987, Jackson et al. 2010; South Africa: Dye \& White 1991, Kaehler \& Froneman 2002; Europe: Hill \& Hawkins 1991, Jenkins et al. 2001, Thompson et al. 2004; North America: Nicotri 1977; Hong Kong: Nagarkar et al. 2004, Nagarkar \& Williams 1997, 1999, Williams 1994, Williams et al. 2000), it is an almost unresearched assemblage on rocky shores in the southwest Atlantic (but see Apolinario et al. 1999).

Spatial and temporal variability of abundance of biofilm on rocky shores are influenced by physical and biological factors. The influences of immersion time 
and wave action allow greater biofilm development lower on the shore (Castenholz 1963, Underwood 1984a, Nagarkar \& Williams 1999) as well as on exposed areas (Thompson et al. 2005). Wave action also modifies macroalgal densities, creating microenvironments where biofilm can grow, while also influencing the density and efficiency of grazers on shores (Jenkins et al. 1999, Jenkins \& Hartnoll 2001). Limpets and littorinids are important slow-moving animals that exert a strong grazing pressure on biofilms (Nicotri 1977, Underwood et al. 1983, Underwood 1984b, Williams 1994, Mak \& Williams 1999, Jenkins et al. 2001). Furthermore, changes in grazing activity due to roughness and inclination of substratum, and aggregation of consumers near crevices, can create spatial variability in biofilm biomass (Benedetti-Cecchi et al. 2001, Stafford \& Davies 2005, Hutchinson et

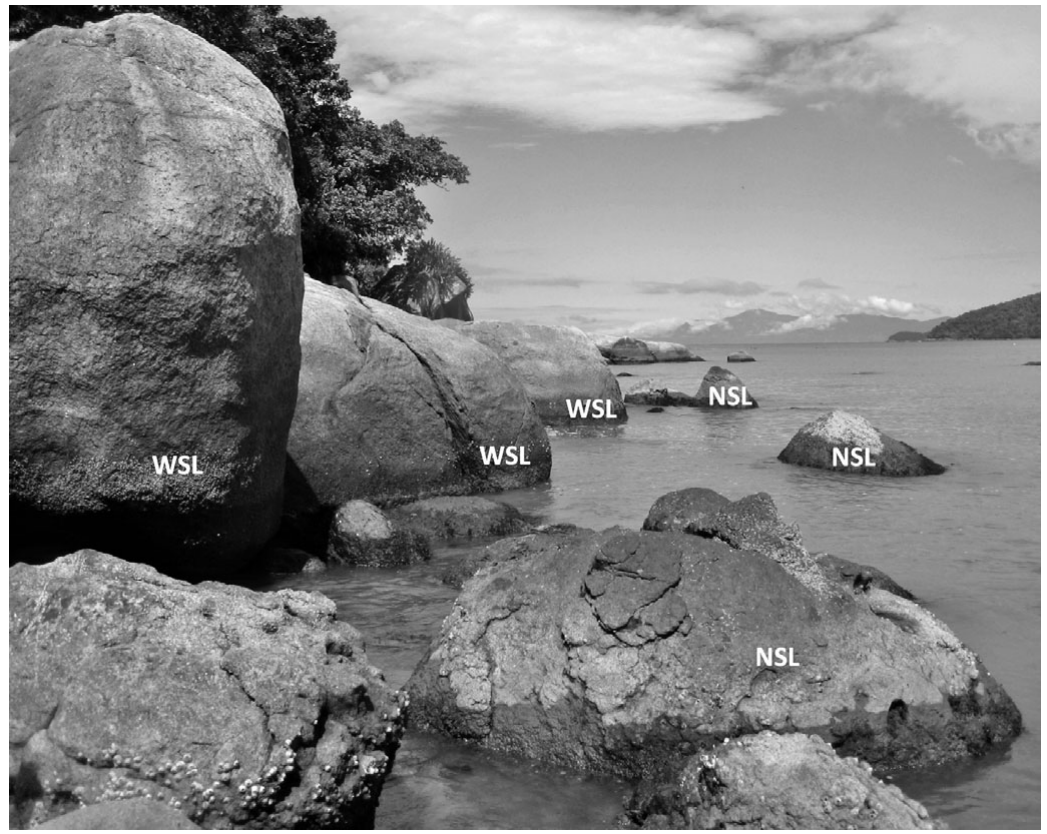

Fig. 1. Rocky shore at the sheltered beach Enseada $\left(23^{\circ} 29^{\prime} 54^{\prime} \mathrm{S}, 45^{\circ} 05^{\prime} 00^{\prime} \mathrm{W}\right)$ in Ubatuba, São Paulo State, Brazil, showing isolated boulders with no supralittoral level (NSL) and rocks with supralittoral level (WSL) al. 2006, Wai \& Williams 2006, Stafford

et al. 2007, Johnson et al. 2008). Temporal changes in biomass of biofilm are also observed. For example, increases in microalgal abundance have been reported during winter months, when grazers are less active, wave action is greater and heat stress is reduced (Castenholz 1963, Underwood 1984a, Hill \& Hawkins 1991, Nagarkar \& Williams 1999, Thompson et al. 2000, 2004).

The central goal of the present study was to investigate spatial patterns of microalgal biofilm on subtropical shores of Brazil, starting out from the hypothesis that environmental gradients (wave action and shore level) and grazing pressure by limpets and littorinids would control the dynamics of biofilm growth. Nonetheless, during the course of our experiments and surveys, we observed some patterns of biofilm distribution that led us to carry out complementary tests. In some of the sheltered sites, we noted the presence of large boulders which were permanently isolated from land, even at the lowest tides (hereafter called isolated boulders, Fig. 1). These isolated boulders were approximately $1.5 \mathrm{~m}$ tall and were totally immersed during high tides, thus lacking a supralittoral level. These isolated boulders were consistently covered by a thick biofilm layer with ochre to silver coloration, while the nearby taller rocks, where the supralittoral level was present, were covered by a very thin and clear layer of biofilm. At the same time, we observed large numbers of Ligia exotica (a fast-moving isopod) on the majority of shores visited; however, the species was apparently never present on the isolated boulders. As populations of L. exotica inhabit mainly the supralittoral, migrating to lower shore levels to forage during periods of emersion, it is reasonable to assume that they are absent on isolated boulders. Although slow-moving animals are important biofilm grazers, fast-moving isopods can also feed on epilithic biofilm (e.g. Sommer 2000, Zimmer 2002), and laboratory-based experiments have demonstrated the influence of the grazing activities of the isopod Idotea chelipes on spatial heterogeneity of microalgal biofilm (Sommer 1999, 2000). Thus, we tested the hypothesis that the presence of $L$. exotica will influence the biomass of biofilm on subtropical shores of Brazil.

\section{MATERIALS AND METHODS}

Patterns of spatial distribution of biofilm. (1) Influence of wave action and shore level: The study was conducted in Ubatuba $\left(23^{\circ} 26^{\prime} 02^{\prime \prime} \mathrm{S}, 4^{\circ} 04^{\prime} 15^{\prime \prime} \mathrm{W}\right.$; Fig. 2), on the north coast of São Paulo State, Brazil. Local tidal range varies from 1.4 to $0.4 \mathrm{~m}$ during spring and neap tides, respectively. Differences in epilithic microalgal biomass (estimated as chlorophyll a concentration) present on moderately exposed (Brava da Fortaleza, Praia Grande and Matarazzo) and sheltered shores (Maranduba, Enseada and Itaguá) (Fig. 2, see Christofoletti et al. in press for details) were quantified in September 2007 and March 2008. Samples consisted 
of 8 rock chips randomly collected from $10 \mathrm{~m}$ long horizontal transects in the midlittoral and the supralittoral of all 6 shores. Minimum distance between replicates was $30 \mathrm{~cm}$ to ensure independence.

Rock chips with a surface area of about $1 \mathrm{~cm}^{2}$ were removed with a chisel from areas free from visible macroalgae and animals. Each fragment was immediately immersed in filtered sea water $(0.2 \mu \mathrm{m})$ and hydrated for 30 min to standardize pigment extraction (Thompson et al. 1999), and placed in scintillation vials containing cooled $\left(-10^{\circ} \mathrm{C}\right) 90 \%$ acetone. Extractions were performed for at least $24 \mathrm{~h}$ at $-10^{\circ} \mathrm{C}$. Fluorescence of room temperature extracts was quantified in a Turner Trilogy fluorometer, previously calibrated with pure chlorophyll a (Sigma ${ }^{\circledR}$ ), using the nonacidification accessory kit to avoid interference from accessory pigments and degradation products (Welschmeyer 1994). Chlorophyll a concentration is reported here as per unit of surface area.

A 4-way mixed model analysis of variance (ANOVA) compared the chlorophyll a concentrations among Time (random, 2 levels), Shore level (fixed, mid- or supralittoral), Exposure (fixed, sheltered and moderately exposed) and Shore (random, 3 levels, nested in Exposure). Cochran's test was used to verify homoscedasticity, and transformations were applied when necessary. Where Cochran's test indicated heterogeneous variances even after transformation, the analysis was

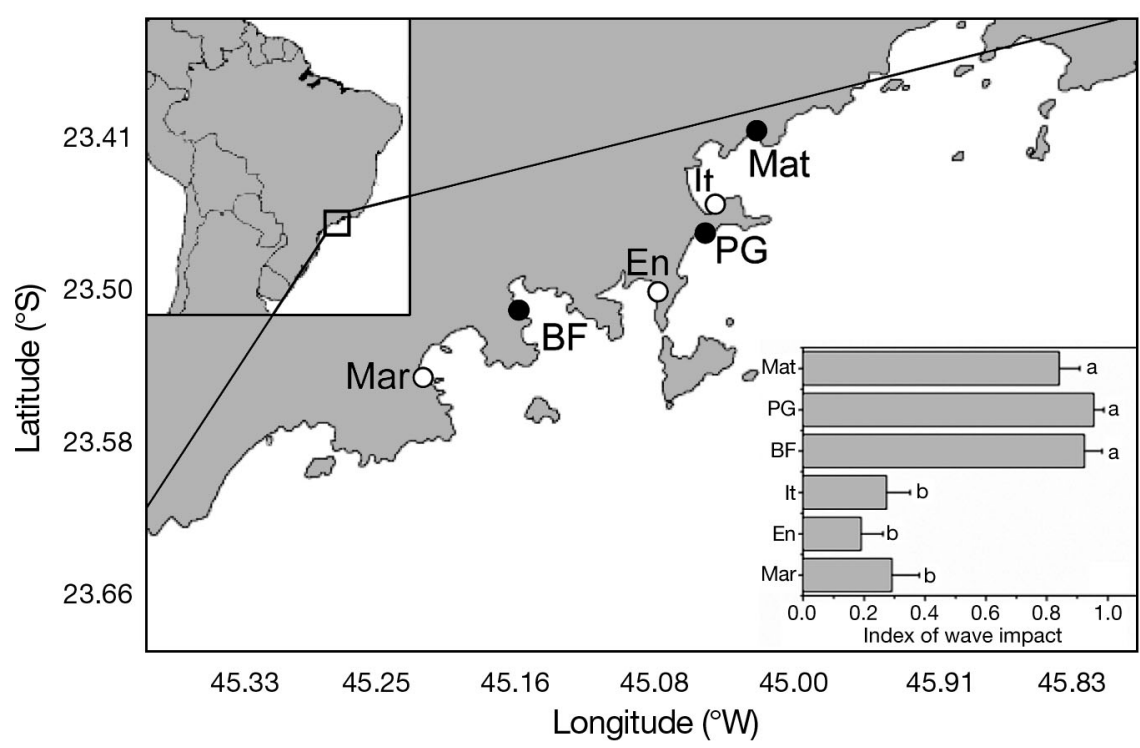

Fig. 2. Study area showing sheltered $(\mathrm{O}, \mathrm{Mar}=$ Maranduba, En $=$ Enseada, $\mathrm{It}=$ Itaguá) and moderately exposed $(\bullet, \mathrm{BF}=$ Brava da Fortaleza, $\mathrm{PG}=$ Praia Grande, Mat $=$ Matarazzo) rocky shores on the north coast of São Paulo State, Brazil. Inset: shores were separated into exposure categories based on an index of wave impact measured simultaneously at all shores at 3 different times, with a significant effect of the factor 'exposure' ( $p<0.001$; see Bueno \& Flores 2010, for details) still performed (using untransformed data) since ANOVA can be considered robust in large balanced designs (Underwood 1997). A post hoc StudentNewman-Keuls (SNK) test was applied for multiple comparisons of the means.

(2) Horizontal scale of variation: Spatial variability of chlorophyll a concentrations at scales of 1,10 and $100 \mathrm{~m}$ was measured in September 2007 at Enseada. This rocky shore was divided into 5 areas of $100 \mathrm{~m}$ width, and the first, third and fifth areas were selected for analysis. Each $100 \mathrm{~m}$ area was then subdivided into 10 sites of $10 \mathrm{~m}$, and 3 sites within each area were randomly selected. The $10 \mathrm{~m}$ sites were then subdivided into 10 sectors of $1 \mathrm{~m}$, and 3 of these were randomly selected in each $10 \mathrm{~m}$ site. Thus, a total of 27 sectors were selected over the shore. Inside each $1 \mathrm{~m}$ sector, 9 rock chips were collected at the midlittoral level to measure chlorophyll a concentration. A fully hierarchical ANOVA model was applied to establish the levels of variation at each spatial scale, using 3 random nested factors: the scales of 1, 10 and $100 \mathrm{~m}$.

Grazing effects of limpets and littorinids. Densities of slow-moving grazers were quantified on the midlittoral and the supralittoral with 30 random digital images (each of $100 \mathrm{~cm}^{2}$ ), taken in February and March 2008 on all 6 rocky shores. Densities and sizes of limpets (mainly Collisella sp. and occasionally Fissurella sp. and Siphonella sp.) in the midlittoral, and littorinids (mainly Nodilittorina lineolata) in the midlittoral and supralittoral zones of all shores were later quantified using Image J software (http:// rsb.info.nih.gov/ij/).

The influence of slow-moving grazers on biomass of biofilm was evaluated using an exclusion experiment conducted during the summer of 2008 (February to April) with 3 treatments: (1) 'exclusion', which consisted of a barrier of a 2-part marine epoxy covered with anti-fouling copper paint (Range et al. 2008), designed to exclude limpets and littorinids in a $100 \mathrm{~cm}^{2}$ area; (2) 'procedural control' consisted of the same 2-part marine epoxy but with the barrier only in the corners of a square sample area, allowing herbivores to enter the area through the lateral opening; and (3) 'natural', which corresponded to an area of intact rocky shore marked at the corners with screws.

In February 2008 the treatments were applied to locations distributed randomly (but not in areas covered by 
visible macroalgae or animals) along $10 \mathrm{~m}$ transects in the midlittoral and supralittoral levels of all shores. To estimate biomass of biofilm, 8 replicate rock chips were collected randomly at the start and end (after $60 \mathrm{~d}$ ) of the treatment. A 5-way ANOVA with 4 fixed and orthogonal factors: Treatment, Time, Shore level and Exposure and a random factor Shore (nested in Exposure) tested the effects of exclusion of slow-moving grazers on chlorophyll a concentration.

Grazing by Ligia exotica. We conducted different surveys at the sheltered shore Enseada (Fig. 2) to test the spatial variability of biomass of biofilm and the grazing activity of Ligia exotica on boulders. We also did a manipulative experiment to study the influence of these isopods on biomass of biofilm.

(1) Biofilm on isolated boulders: In April 2008, rocks were classified into 2 groups: 'with supralittoral level' (WSL) and 'with no supralittoral level' (NSL: the isolated boulders where the supralittoral level is absent; Fig. 1). Chlorophyll a concentrations were estimated from 1 rock chip collected from the midlittoral of 10 different rocks from each group (WSL and NSL) and compared using a $t$-test.

(2) Spatial patterns of grazing activity by Ligia exotica on shore: The grazing activity of $L$. exotica was estimated in 6 independent areas, each of approximately $1 \mathrm{~m}^{2}$, on plots on each WSL and NSL boulder. These areas were observed for $10 \mathrm{~min}$ each, and the number of isopods present was counted. This method is an estimate of the foraging pressure by consumers but not the abundance of the population. It was chosen since the time spent by consumers in a specific area is more important to prey than their density (Burrows et al. 1999).

(3) Grazing influence of Ligia exotica on biofilm: In April 200830 rock chips were removed from the midlittoral of an area with visibly greater abundance of biofilm (NSL boulders) and divided into 3 treatments: 'exclusion', 'herbivory' and 'control'. In the exclusion treatment, rock chips (surface area about $1 \mathrm{~cm}^{2}$ ) were fixed onto PVC plates using epoxy, moved to the midlittoral of WSL boulders and placed inside cages to prevent foraging by isopods. Cages $(9 \times 9 \times 5 \mathrm{~cm})$ were made with a PVC structure covered by a microfiber net (1.4 $\mathrm{mm}$ mesh), and both plates and cages were fixed to the rock using screws. In the herbivory treatment, chips were fixed onto plates and moved to the midlittoral of WSL boulders where chips were accessible to isopods. In the control treatment, fragments were fixed onto plates and kept at the same tidal height on isolated boulders where there were no isopods, therefore acting as a control for handling. Some preliminary results suggested very fast rates of grazing; thus, after $24 \mathrm{~h}$, all chips were re-collected for quantification of chlorophyll $a$. Since it was a short-term experiment, the effects of cages (shade or slower water flow) on biofilm were not considered and, therefore, we did not use procedural controls with partial cages. ANOVA and SNK tests were applied to test the effects of the exclusion of $L$. exotica on amounts of chlorophyll $a$.

\section{RESULTS}

\section{Patterns of spatial distribution of biofilm}

There was no consistent influence of environmental factors (wave exposure, shore level, temporal variation) on biofilm abundance, while significant variation was found among shores (Table 1: ANOVA, Shore level $\times$ Time $\times$ Shore (exposure) interaction, $\mathrm{p}<0.001$ ). The midlittoral of Praia Grande showed an extreme temporal variation, presenting both the highest (September 2007: $23.35 \pm 4.19 \mathrm{\mu g} \mathrm{cm}^{-2} \mathrm{SE}$ ) and lowest (March 2008: $0.12 \pm$ $0.03 \mathrm{\mu g} \mathrm{cm}^{-2}$ ) chlorophyll $a$ concentrations found at this level among all shores (Fig. 3). In general, there was a lower abundance of microalgae at the supralittoral level, where chlorophyll a concentration ranged from $0.05 \pm$ $0.01 \mathrm{\mu g} \mathrm{cm}^{-2}$ (September 2007 at Brava da Fortaleza) to $1.47 \pm 0.78 \mu \mathrm{g} \mathrm{cm}^{-2}$ (March 2008 at Matarazzo) (Fig. 3). However, differences were only significant at Matarazzo, Enseada and Praia Grande shores during winter 2007 and at Itaguá during March 2008 (Table 1: SNK test of Shore level $\times$ Time $\times$ Shore (exposure) interaction, $\mathrm{p}<$ 0.05 ; Fig. 3). Temporal differences were found only in the midlittoral, with higher chlorophyll a concentrations during September 2007 than March 2008 at Enseada and Praia Grande; the opposite pattern, with a higher chloro-

Table 1. Results of ANOVA examining the effects of Time (random, 2 levels), Shore level (fixed, mid- or supralittoral), Exposure (fixed, sheltered or moderately exposed) and Shore (random, 3 levels, nested in Exposure, see Fig. 2 for details of locations) on chlorophyll a concentrations in biofilms on rocky shores on the north coast of São Paulo State, Brazil. Cochran's test $=0.5648(p<0.01)$. SNK test results for the significant interaction (in bold) are presented in Fig. 3

\begin{tabular}{|lrrcc|}
\hline Source of variation & df & \multicolumn{1}{c}{ MS } & $F$ & $\mathrm{p}$ \\
\hline Time $=\mathrm{Ti}$ & 1 & 199.35 & 0.93 & 0.3886 \\
Wave Exposure = Ex & 1 & 77.91 & Not tested & \\
Shore $($ Ex) $=\mathrm{Sh}(\mathrm{Ex})$ & 4 & 132.60 & 0.62 & 0.6721 \\
Shore level = Le & 1 & 760.83 & Not tested & \\
Ti $\times$ Ex & 1 & 238.91 & 1.12 & 0.3498 \\
Ti $\times$ Sh $($ Ex $)$ & 4 & 213.51 & 20.58 & $<0.001$ \\
Ti $\times$ Le & 1 & 189.92 & 1.10 & 0.3540 \\
Ex $\times$ Le & 1 & 44.52 & Not tested & \\
Le $\times$ Sh $($ Ex $)$ & 4 & 127.26 & 0.74 & 0.6136 \\
Ti $\times$ Ex $\times$ Le & 1 & 214.33 & 1.24 & 0.3282 \\
Le $\times$ Ti $\times$ Sh $($ Ex $)$ & 4 & 173.09 & 16.68 & $<\mathbf{0 . 0 0 1}$ \\
Residual & 168 & 10.38 & & \\
& & & & \\
\end{tabular}




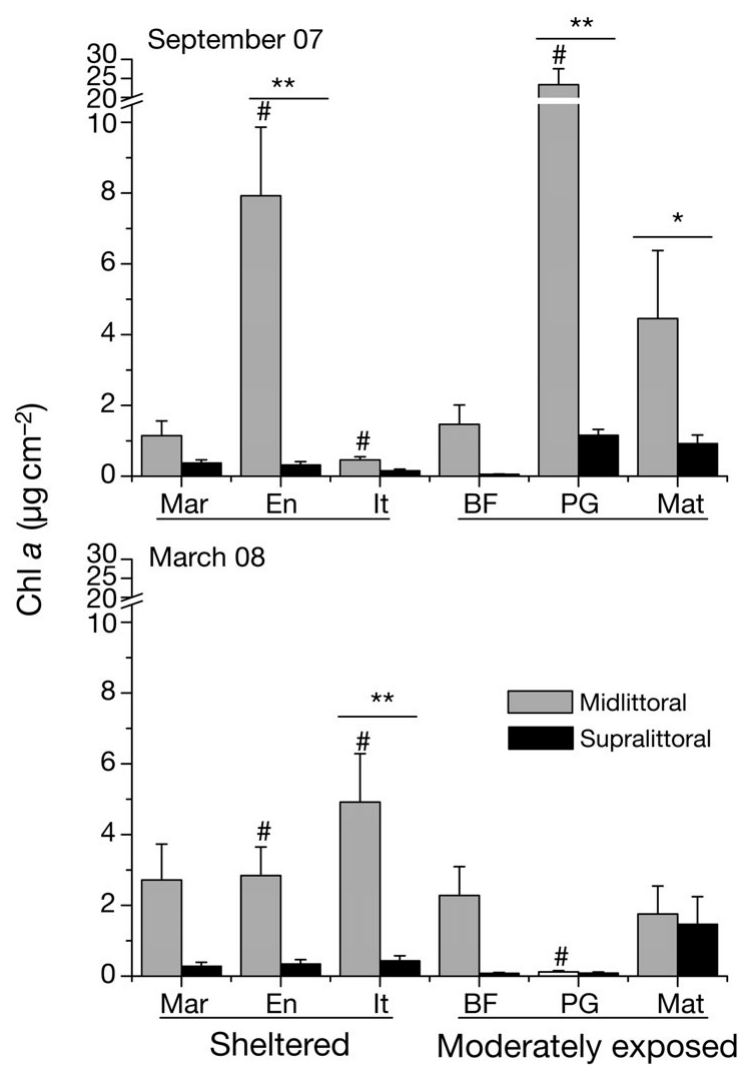

Fig. 3. Chlorophyll a (chl a) concentration (mean $\pm \mathrm{SE}$ ) of biofilm at mid- and supralittoral shore levels of sheltered (Mar = Maranduba, En = Enseada, It = Itaguá $)$ and moderately exposed $(\mathrm{BF}=$ Brava da Fortaleza, $\mathrm{PG}=$ Praia Grande, Mat = Matarazzo) rocky shores on the north coast of São Paulo State, Brazil, during September 2007 and March 2008. Symbols ${ }^{*}(p<0.05)$ and ${ }^{* *}(p<0.01)$ indicate significant differences between shore levels on the same shore in the same month; \# $(\mathrm{p}<0.05)$ indicates differences between months at the same level on the same shore (ANOVA for SNK test results is shown in Table 1)

phyll a concentration in March 2008 than in September 2007, was observed at Itaguá ( $<$ 0.01) (Fig. 3). Significant horizontal variation in chlorophyll a concentration was found at the $1 \mathrm{~m}$ scale (Table 2), with values ranging from $1.61 \pm 0.55 \mu \mathrm{g} \mathrm{cm}{ }^{-2}$ to $45.98 \pm 6.28 \mu \mathrm{g} \mathrm{cm}^{-2}$.

\section{Grazing effects of limpets and littorinids}

Densities of slow-moving grazers tended to be greater on moderately exposed shores, although they varied locally (Table 3). Maranduba presented the second greatest abundance of limpets (mean \pm SD: $480 \pm 532.7$ ind. $\left.\mathrm{m}^{-2}\right)$ and littorinids $(1588.3 \pm 3693.3 \mathrm{ind}$. $\mathrm{m}^{-2}$ ) among all shores, while other shel-
Table 2. ANOVA for chlorophyll a concentration related to horizontal scale of variation (1 m, $10 \mathrm{~m}$ and $100 \mathrm{~m}$ ) at Enseada shore, in Ubatuba, São Paulo State, Brazil, in September 2007. Cochran's test $=0.1599(p<0.01)$

\begin{tabular}{|lrrrr|}
\hline Source of variation & df & MS & $F$ & p \\
\hline $100 \mathrm{~m}$ & 2 & 2867.10 & 1.18 & 0.3706 \\
$10 \mathrm{~m}(100 \mathrm{~m})$ & 6 & 2436.51 & 4.68 & 0.0049 \\
$1 \mathrm{~m}(10 \mathrm{~m}(100 \mathrm{~m}))$ & 18 & 520.68 & 6.33 & $<0.001$ \\
Residual & 216 & 82.27 & & \\
\hline
\end{tabular}

tered areas (Enseada and Itaguá) had the lowest densities of slow-moving herbivores (between 0 and $171.1 \pm$ 945.1 ind. $\mathrm{m}^{-2}$; Table 3 ).

Chlorophyll a concentration decreased as density of slow-moving herbivores increased on shores (Fig. 4 ; $r=$ $0.83, \mathrm{p}<0.05)$. Nonetheless, despite this significant correlation at the scale of shores (tens of meters), slowmoving grazers had a weak influence on chlorophyll $a$ concentration at smaller scales, as shown by the results of exclusion experiments (5-way ANOVA, Cochran's test $=0.1174, \mathrm{p}<0.01$; SNK test of the interaction: Treatment $\times$ Shore level $\times$ Time $\times$ Shore (exposure), $\mathrm{df}$ $=8, \mathrm{MS}=17.34, F=8.39, \mathrm{p}<0.001)$. A significant increase in biomass of biofilm over time was only observed in the midlittoral at Enseada, for exclusion and procedural control treatments (Fig. 5). In addition, inconsistent variation was observed in the supralittoral of the exposed shore at Matarazzo, where chlorophyll a concentration increased over time in the control $(\mathrm{p}<0.05)$.

\section{Grazing by Ligia exotica}

Chlorophyll a concentrations were significantly higher on isolated boulders with no supralittoral level $\left(\mathrm{NSL}\right.$, mean $\pm \mathrm{SE}: 5.60 \pm 0.57 \mu \mathrm{g} \mathrm{cm}^{-2}$ ) than on rocks with supralittoral level (WSL: $0.83 \pm 0.15 \mu \mathrm{g} \mathrm{cm}^{-2}$ )

Table 3. Density and size (mean \pm SD) of limpets (midlittoral) and littorinids (midlittoral + supralittoral) on rocky shores of on the north coast of São Paulo State, Brazil, during summer 2008. na: not applicable

\begin{tabular}{|lccccc|}
\hline \multirow{2}{*}{ Shore } & \multicolumn{2}{c}{ Limpets } & & \multicolumn{2}{c|}{ Littorinids } \\
& Density $\left(\mathrm{m}^{-2}\right)$ & Size $(\mathrm{mm})$ & & Density $\left(\mathrm{m}^{-2}\right)$ & Size $(\mathrm{mm})$ \\
\hline Sheltered & & & & \\
Maranduba & $480 \pm 532.7$ & $4.9 \pm 1.9$ & & $1588.3 \pm 3693.3$ & $2.3 \pm 0.5$ \\
Enseada & $6.7 \pm 25.4$ & $5.2 \pm 2.2$ & & $171.7 \pm 945.1$ & $2.5 \pm 0.4$ \\
Itaguá & 0 & na & & $1.7 \pm 12.9$ & $2.7 \pm 0.6$ \\
Moderately exposed & & & & \\
Brava da Fortaleza & $123.3 \pm 263.5$ & $7.7 \pm 2.8$ & & $375.0 \pm 634$ & $2.9 \pm 0.5$ \\
Praia Grande & $86.7 \pm 138.3$ & $7.3 \pm 2.5$ & & $4203.3 \pm 6140.5$ & $2.8 \pm 0.7$ \\
Matarazzo & $1033.3 \pm 779.6$ & $5.8 \pm 1.1$ & & $510.0 \pm 912.8$ & $3.7 \pm 0.5$ \\
\hline
\end{tabular}




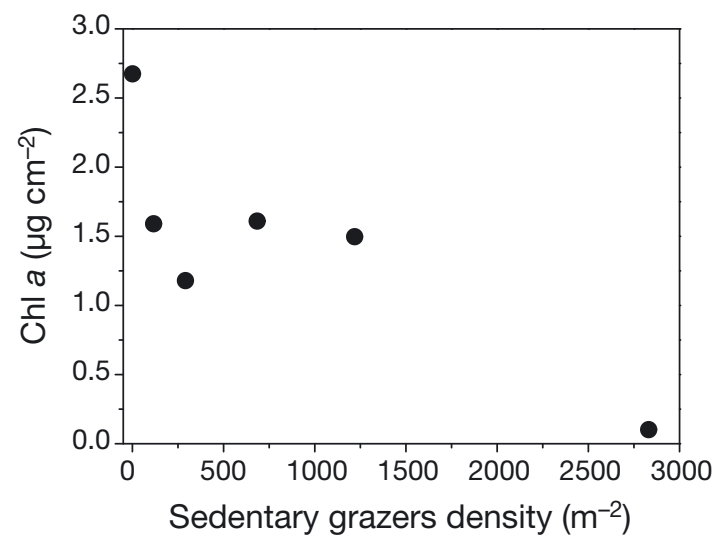

Fig. 4. Correlation of total density of slow-moving herbivores (limpets and littorinids) against chl a concentration on rocky shores on the north coast of São Paulo State, Brazil, in March 2008

(Fig. 6A; $t$-test, df $=18, t=-8.14, \mathrm{p}<0.001$ ). No Ligia exotica individuals were observed in NSL, whilst in WSL there were $1.56 \pm 0.76$ ind $\mathrm{min}^{-1} \mathrm{~m}^{-2}$. Grazing pressure of these isopods significantly reduced chlorophyll a concentration in the herbivory treatment in relation to both exclusion and control treatments (Fig. 6B; ANOVA, Cochran's test $=0.5696 \mathrm{~ns}, \mathrm{df}=2$, $\mathrm{MS}=37.52, F=8.85, \mathrm{p}=0.0011$ ).

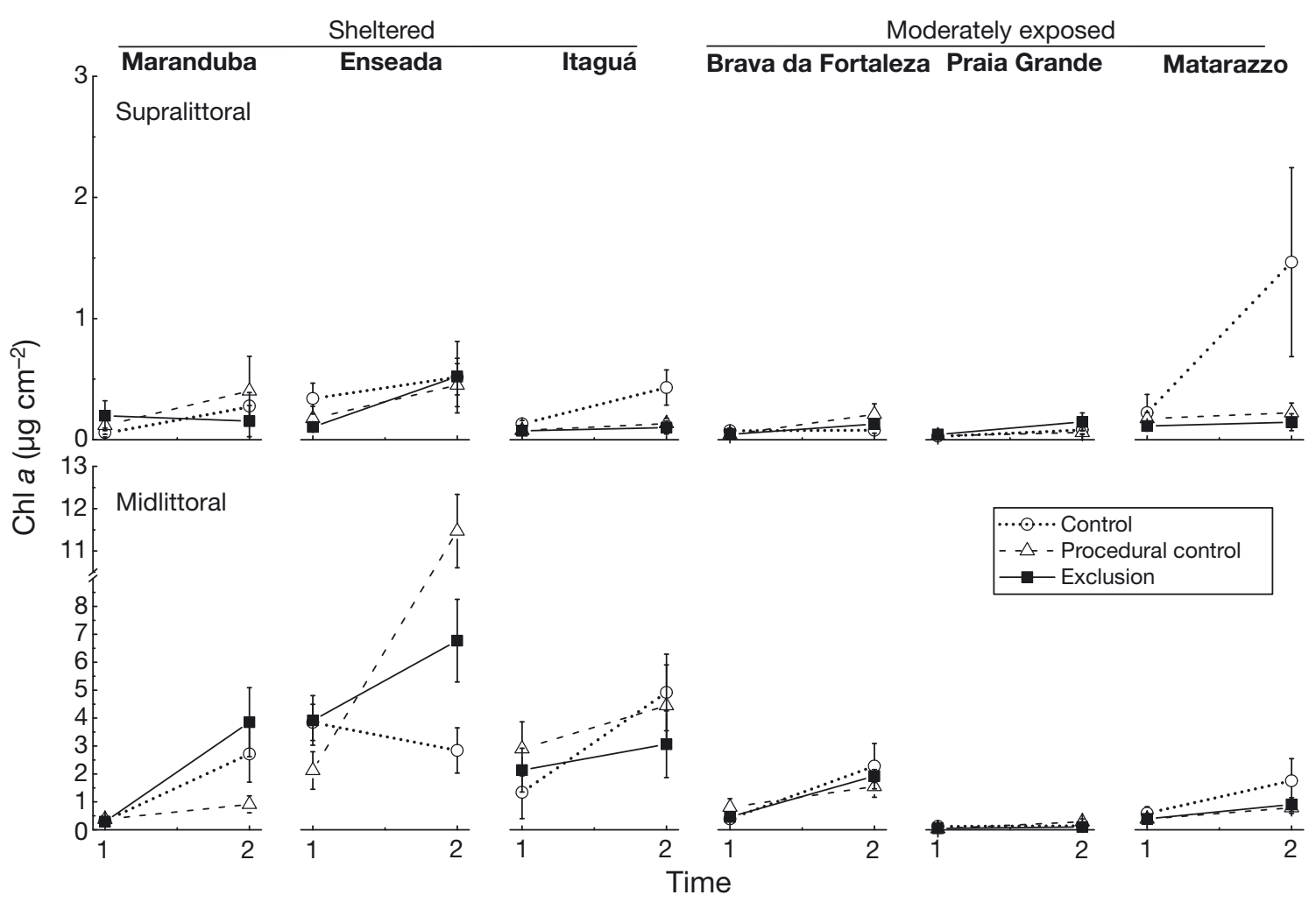

Fig. 5. Chlorophyll a concentration (mean \pm SE) of biofilm in an exclusion experiment to study the impact of slow-moving grazers in mid- and supralittoral shore levels of sheltered and moderately exposed rocky shores on the north coast of São Paulo State, 


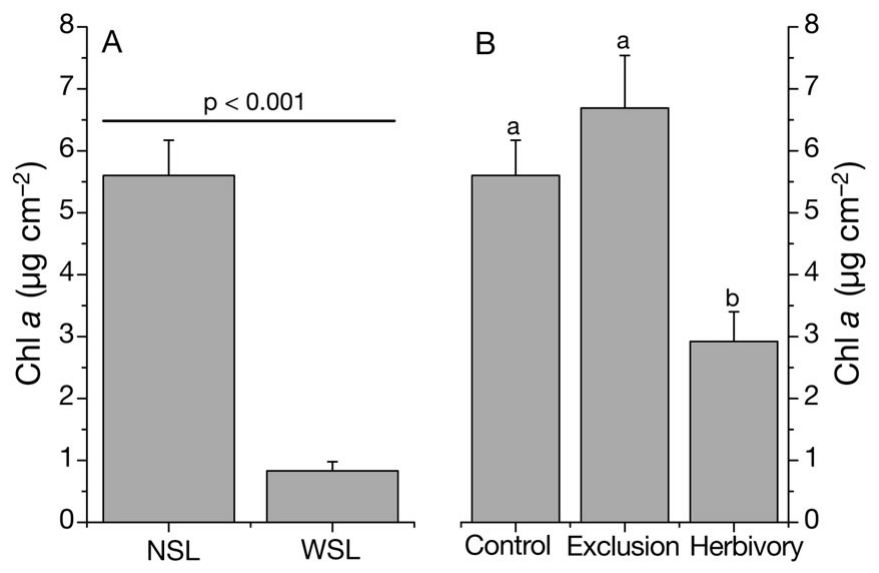

Fig. 6. Chlorophyll a concentration (mean \pm SE) on rocky shores on the north coast of São Paulo State, Brazil, in relation to (A) geomorphology of shore (NSL: isolated boulders with no supralittoral level; WSL: rocks with supralittoral level) and (B) fast-moving grazer pressure on the biomass of biofilm in an exclusion experiment (Control: natural NSL rock chips; Exclusion: NSL rock chips inside cages not accessible to Ligia exotica; Herbivory: NSL rock chips accessible to $L$. exotica). In (B) the letters ' $a$ ' and ' $b$ ' identify means that are significantly different from each other (SNK test, $\mathrm{p}<0.01$ )

the control of microalgal biomass was evident at the scale of shores (Fig. 4), but it was not consistent at small spatial scales (Fig. 5). The homogeneous patterns of chlorophyll a found among treatments at the smallest scale appear to be caused by the foraging activities of Ligia exotica and are similar to effects of the isopod Idotea spp. (Sommer 1999, 2000). This explanation is also supported by the fact that an increase in abundance of biofilm found after exclusion of slow-moving grazers occurred only on Enseada, which has many isolated boulders without L. exotica. These experiments were performed before our hypothesis relating to the influence of these isopods on biofilm biomass was formed, and before replicates were allocated to WSL and NSL boulders. As L. exotica has no influence on NSL boulders, the grazing pressure on these rocks was due only to slow-moving animals. Thus, our results suggest that, at large scales (hundreds of meters), grazing effects on abundance of biofilm in this subtropical region are the result of an additive effect of slow and fast-moving grazers. On the other hand, at small spatial scales, fastmoving grazers played a more important role, masking the effect of slow-moving animals.

In addition to the spatial variability in biomass of biofilm, our study found amounts of chlorophyll a per area of rock similar to those found in other tropical areas (Nagarkar \& Williams 1999, Williams et al. 2000, Kaehler \& Froneman 2002), but greater than those found in more temperate regions (e.g. Underwood 1984b, Dye \& White 1991, Jenkins et al. 2001, Thompson et al. 2005). However, we do not have information on epilithic components of this biofilm, and further studies of the composition of this assemblage are needed to evaluate the dominant species, their relative contribution and how they vary geographically, temporally and under grazing pressure (e.g. Hill \& Hawkins 1991, Nagarkar \& Williams 1997, 1999, Jackson et al. 2010, Skov et al. 2010). In this context, the unexpectedly greater biomass of biofilm in some control treatments in our experiment on the exclusion of slow-moving grazers may be a result of changes in the species composition or biomass due to grazing activity (e.g. Williams et al. 2000, Kaehler \& Froneman 2002, Skov et al. 2010) or to negative effects of copper on microalgal cover (see Range et al. 2008 for review).

Although some trends found in our study corresponded to the literature, the influence of environmental conditions on spatial distribution of biofilm was inconsistent (Table 1, Fig. 3). We did not observe a consistently greater chlorophyll a concentration on moderately exposed shores (Thompson et al. 2005), during winter months (Underwood 1984a, Nagarkar \& Williams 1999, Jenkins et al. 2001, Thompson et al. 2005) or at lower shore levels (Nicotri 1977, Underwood 1984a, MacLulich 1987). However, greater biomasses of biofilm occurred in the midlittoral than in the supralittoral, matching patterns observed by Underwood (1984a) and Nagarkar \& Williams (1999); this result may reflect the importance of a reduction in desiccation stress and enhancement of nutrient supply with greater immersion times. We consider 3 main explanations for the inconsistent patterns: (1) environmental gradients at the locations studied may be too narrow to yield consistent spatial patterns in the biomass of biofilm; alternatively, the environmental gradients may produce patterns, but these were masked in this study by (2) grazing pressure, or (3) other physicochemical factors not investigated.

Initially, Hypothesis (1) seems more parsimonious, due to the relatively narrow environmental gradients found in subtropical regions. Tidal amplitude $(0.4$ to $1.4 \mathrm{~m})$, summer to winter air and sea temperature gradients (amplitude of $6^{\circ} \mathrm{C}$ and $4^{\circ} \mathrm{C}$, respectively), as well as photoperiod, are not as extreme as in temperate regions where clear environmental effects have been observed (Jenkins et al. 2001, Thompson et al. 2004, 2005). Nonetheless, a significant environmental influence on biomass of biofilm has been found in other tropical regions, where there is a clear vertical pattern of distribution of biofilm and temporal variation is driven by environmental conditions (Nagarkar \& Williams 1999) that result in a seasonal change in the relative importance of physical and biological influences on biofilm (Williams et al. 2000). Thus, it is reasonable to suppose that both grazing control (Hypothesis 2) and other physico-chemical factors (Hypothesis 3) might have been responsible for the observed patterns. 
Hypothesis (2) is not supported by the literature, since studies found consistent environmental effects even under stronger grazing influence (e.g. Underwood 1984b, Mak \& Williams 1999, Kaehler \& Froneman 2002). These studies place slow-moving grazers as the main consumer of biofilm. In the Ubatuba region, fast-moving isopods appear to provide an intense additional grazing pressure on microalgal abundance. However, Mak \& Williams (1999) found a great influence of littorinids on biofilm biomass on shores in Hong Kong, despite the presence of Ligia spp., in contrast to the results of our study. Differences in grazer densities can influence consumer pressure (see Jenkins et al. 2008 for a review) and complicate comparisons with other geographic regions. The effects of different densities of Ligia exotica were not tested here and it is possible that this factor, together with the number of isolated boulders among shores, were responsible for the variability of biofilm biomass at the scale of shore. Indeed, the significant correlation between abundance of slow-moving grazers and chlorophyll a concentrations on shores (Fig. 4) support this explanation. Thus, stronger grazing control presented by slow- and fastmoving herbivores may be masking the effects of environmental conditions in this subtropical area of Brazil.

Some temporal variation in biofilm biomass was found at specific shores, suggesting that factors emerging at the scale of shore can influence the balance between environmental and biological controls and highlighting the importance of clarifying the scale of variation (e.g. Underwood \& Chapman 1996, Denny et al. 2004). Although grazing control may have strong influence on biofilm biomass in our area, other physico-chemical factors may also play a role (hypothesis 3). The north coast of São Paulo State is characterized by a large number of enclosed bays (Fig. 2) where oceanographic processes, such as currents and freshwater discharges vary at the scale of kilometers (e.g. Mahiques et al. 1998). As nearshore nutrients may influence primary production of rocky shore assemblages (e.g. Menge et al. 1997), the effects of wave exposure on biolfilm biomass may be masked by the different nutrient regimes present at these shores.

Our goal was to understand the effect of environmental factors and slow-moving grazers on spatial variability of biofilm in this subtropical system within a framework developed and validated in many studies around the globe. Our results suggest that environmental influences on the biomass of biofilm are masked by variability of grazing pressure across different scales within this system. We found that this variability is due to the additional contribution of grazing pressure by the fast-moving isopod Ligia exotica to that of slow-moving grazers, like limpets and littorinids. However, the relative contribution of these fast-moving isopods to overall grazing pressure is also related to variations in shore geomorphology, particularly at sites with isolated boulders.

Acknowledgements. We thank R. Tonini, F. Gianinni, K. Mello, A. Pinto, L. Silva, G. Bergamaschi and R. Ota for their help during the field work and laboratory analysis, especially D. Jorge during the winter activities. We are also grateful to A. Majer, S. Jenkins and the anonymous referees for their valuable comments on the manuscript and the School of Ocean Sciences, Bangor University (UK), which hosted R.A.C. during the preparation of the manuscript. This work was supported by research funds granted by the Fundação de Amparo à Pesquisa do Estado de São Paulo to R.A.C. (06/00559-4 and 06/60237-0).

\section{LITERATURE CITED}

Anderson MJ (1995) Variations in biofilms colonizing artificial surfaces: seasonal effects and effects of grazers. J Mar Biol Assoc UK 75:705-714

Apolinario M, Coutinho R, Baeta-Neves MH (1999) Periwinkle (Gastropoda: Littorinidae) habitat selection and its impact upon microalgal populations. Rev Bras Biol 59: 211-218

Benedetti-Cecchi L, Bulleri F, Acunto S, Cinelli F (2001) Scales of variation in the effects of limpets on rocky shores in the northwest Mediterranean. Mar Ecol Prog Ser 209: 131-141

Bueno M, Flores AAV (2010) Tidal-amplitude rhythms of larval release: variable departure from presumed optimal timing among populations of the mottled shore crab. J Mar Biol Assoc UK 90:859-865

Burrows MT, Kawai K, Hughes RN (1999) Foraging by mobile predators on a rocky shore: underwater TV observations of movements of blennies Lipophrys pholis and crabs Carcinus maenas. Mar Ecol Prog Ser 187:237-250

Castenholz RW (1963) An experimental study of the vertical distribution of littoral marine diatoms. Limnol Oceanogr 8:450-462

Christofoletti RA, Takahashi CK, Oliveira DN, Flores AAV (in press) Spatial and temporal variation of sedentary consumers and sessile organisms on shores of a subtropical area of the southwest Atlantic. J Mar Biol Assoc UK. doi:10.1017/S0025315410001992

Denny MW, Helmuth B, Leonard GH, Harley CDG, Hunt LJH, Nelson EK (2004) Quantifying scale in ecology: lessons from a wave-swept shore. Ecol Monogr 74:513-532

Doi H, Chang KH, Obayashi Y, Yoshihara M and others (2008) Attached microalgae contribute to planktonic food webs in bays with fish and pearl oyster farms. Mar Ecol Prog Ser 353:107-113

Dye AH, White DRA (1991) Intertidal microalgal production and molluscan herbivory in relation to season and elevation on two rocky shores on the east coast of southern Africa. S Afr J Mar Sci 11:483-489

Hill AS, Hawkins SJ (1991) Seasonal and spatial variation of epilithic microalgal distribution and abundance and its ingestion by Patella vulgata on a moderately exposed rocky shore. J Mar Biol Assoc UK 71:403-423

> Hillebrand H (2009) Meta-analysis of grazer control of periphyton biomass across aquatic ecosystems. J Phycol 45: 798-806

Huang R, Boney AD (1984) Growth interactions between littoral diatoms and juvenile marine algae. J Exp Mar Biol Ecol 81:21-45 
Hung OS, Thiyagarajan V, Zhang R, Wu RSS, Qian PY (2007) Attachment of Balanus amphitrite larvae to biofilms originating from contrasting environments. Mar Ecol Prog Ser 333:229-242

> Hutchinson N, Nagarkar S, Aitchison JC, Williams GA (2006) Microspatial variation in marine biofilm abundance on intertidal rock surfaces. Aquat Microb Ecol 42:187-197

- Jackson AC, Underwood AJ, Murphy RJ, Skilleter GA (2010) Latitudinal and environmental patterns in abundance and composition of epilithic microphytobenthos. Mar Ecol Prog Ser 417:27-38

Jenkins SR, Hartnoll RG (2001) Food supply, grazing activity and growth rate in the limpet Patella vulgata L.: a comparison between exposed and sheltered shores. J Exp Mar Biol Ecol 258:123-139

Jenkins SR, Hawkins SJ, Norton TA (1999) Direct and indirect effects of a macroalgal canopy and limpet grazing in structuring a sheltered inter-tidal community. Mar Ecol Prog Ser 188:81-92

> Jenkins SR, Arenas F, Arrontes J, Bussell J and others (2001) European-scale analysis of seasonal variability in limpet grazing activity and microalgal abundance. Mar Ecol Prog Ser 211:193-203

> Jenkins SR, Moore P, Burrows MT, Garbary DJ and others (2008) Comparative ecology of North Atlantic shores: Do differences in players matter for process? Ecology 89: S3-S23

Johnson MP, Hanley ME, Frost NJ, Mosley MWJ, Hawkins SJ (2008) The persistent spatial patchiness of limpet grazing. J Exp Mar Biol Ecol 365:136-141

Kaehler S, Froneman PW (2002) Herbivore-mediated increase in the photosynthetic capacity of marine biofilms: indirect effects of changing microalgal assemblage composition. Mar Ecol Prog Ser 234:15-22

> MacLulich JH (1986) Colonization of bare rock surfaces by microflora in a rocky intertidal habitat. Mar Ecol Prog Ser 32:91-96

MacLulich JH (1987) Variations in the density and variety of intertidal epilithic microflora. Mar Ecol Prog Ser 40: 285-293

Magalhães CM, Bordalo AA, Wiebe WJ (2003) Intertidal biofilms on rocky substratum can play a major role in estuarine carbon and nutrient dynamics. Mar Ecol Prog Ser 258:275-281

Mahiques MM, Tessler MG, Furtado VV (1998) Characterization of energy gradient in enclosed bays of Ubatuba region, south-eastern Brazil. Estuar Coast Shelf Sci 47: 431-446

Mak YM, Williams GA (1999) Littorinids control high intertidal biofilm abundance on tropical, Hong Kong rocky shores. J Exp Mar Biol Ecol 233:81-94

Menge BA, Daley BA, Wheeler PA, Dahlhoff E, Sanford E, Strub PT (1997) Benthic-pelagic links and rocky intertidal communities: bottom-up effects on top-down control? Proc Natl Acad Sci USA 94:14530-14535

> Nagarkar S, Williams GA (1997) Comparative techniques to quantify cyanobacteria dominated epilithic biofilms on tropical rocky shores. Mar Ecol Prog Ser 154:281-291

> Nagarkar S, Williams GA (1999) Spatial and temporal variation of cyanobacteria-dominated epilithic communities on a tropical shore in Hong Kong. Phycologia 38:385-393

> Nagarkar S, Williams GA, Subramanian G, Saha SK (2004) Cyanobacteria-dominated biofilms: a high quality food resource for intertidal grazers. Hydrobiologia 512:89-95

> Nicotri ME (1977) Grazing effects of four marine intertidal herbivores on the microflora. Ecology 58:1020-1032

Range P, Chapman MG, Underwood AJ (2008) Field experiments with 'cageless' methods to manipulate grazing gas- tropods on intertidal rocky shores. J Exp Mar Biol Ecol 365:23-30

Skov MW, Volkelt-Igoe M, Hawkins SJ, Jesus B, Thompson RC, Doncaster CP (2010) Past and present grazing boosts the photo-autotrophic biomass of biofilms. Mar Ecol Prog Ser 401:101-111

- Sommer U (1999) The impact of herbivore type and grazing pressure on benthic microalgal diversity. Ecol Lett 2: 65-69

Sommer U (2000) Benthic microalgal diversity enhanced by spatial heterogeneity of grazing. Oecologia 122:284-287

Stafford R, Davies MS (2005) Spatial patchiness of epilithic biofilm caused by refuge-inhabiting high shore gastropods. Hydrobiologia 545:279-287

Stafford R, Davies MS, Williams GA (2007) Computer simulations of high shore littorinids predict small-scale spatial and temporal distribution patterns on rocky shores. Mar Ecol Prog Ser 342:151-161

> Thompson RC, Tobin ML, Hawkins SJ, Norton TA (1999) Problems in extraction and spectrophotometric determination of chlorophyll from epilithic microbial biofilms: toward a standard method. J Mar Biol Assoc UK 79: $551-558$

Thompson RC, Roberts MF, Norton TA, Hawkins SJ (2000) Feast or famine for intertidal grazing molluscs: a mismatch between seasonal variations in grazing intensity and the abundance of microbial resources. Hydrobiologia 440:357-367

Thompson RC, Norton TA, Hawkins SJ (2004) Physical stress and biological control regulate the producer-consumer balance in intertidal biofilms. Ecology 85:1372-1382

- Thompson RC, Moschella PS, Jenkins SR, Norton TA, Hawkins SJ (2005) Differences in photosynthetic marine biofilms between sheltered and moderately exposed rocky shores. Mar Ecol Prog Ser 296:53-63

Underwood AJ (1984a) The vertical-distribution and seasonal abundance of intertidal microalgae on a rocky shore in New South Wales. J Exp Mar Biol Ecol 78:199-220

> Underwood AJ (1984b) Vertical and seasonal patterns in competition for microalgae between intertidal gastropods. Oecologia 64:211-222

Underwood AJ (1997) Experiments in ecology. Their logical design and interpretation using analysis of variance. Cambridge University Press, Cambridge

- Underwood AJ, Chapman MG (1996) Scales of spatial patterns of distribution of intertidal snails. Oecologia 107: $212-224$

> Underwood AJ, Denley EJ, Moran MJ (1983) Experimental analyses of the structure and dynamics of mid-shore rocky intertidal communities in New South Wales. Oecologia 56: 202-219

Wai TC, Williams GA (2006) Monitoring spatio-temporal variation in molluscan grazing pressure in seasonal, tropical rock pools. Mar Biol 149:1139-1147

Welschmeyer NA (1994) Fluorometric analysis of chlorophyll $\mathrm{a}$ in the presence of chlorophyll $\mathrm{b}$ and pheopigments. Limnol Oceanogr 39:1985-1992

> Williams GA (1994) The relationship between shade and molluscan grazing in structuring communites on a moderately-exposed tropical rocky shore. J Exp Mar Biol Ecol 178:79-95

Williams GA, Davies MS, Nagarkar S (2000) Primary succession on a seasonal tropical rocky shore: the relative roles of spatial heterogeneity and herbivory. Mar Ecol Prog Ser 203:81-94

Zimmer M (2002) Nutrition on terrestrial isopods (Isopoda: Oniscidea): an evolutionary-ecological approach. Biol Rev Camb Philos Soc 77:455-493

Submitted: August 11, 2009; Accepted: December 6, 2010

Proofs received from author(s): February 17, 2011 